\title{
Risk Factors for Delinquency among Adolescent Boys in Trinidad and Tobago
}

\author{
A Noel, C Donald, G Hutchinson
}

\begin{abstract}
Objective: Various risk factors for juvenile delinquency have been identified but the extent to which they are applicable in Trinidad and Tobago has not been investigated. We conducted a case-control study comparing risk factors in delinquent and non-delinquent boys.

Methods: Assessment of delinquent behaviour over the course of the preceding year was undertaken via the self-report delinquency scale while the Rosenberg self-esteem scale was used to assess self-esteem.

Results: We found low academic achievement, living environment and family arrests positively correlated with delinquency in adolescent boys in Trinidad and Tobago. However, contrary to our hypotheses, self-esteem, punishment and family structure (single parent families) were found to be unrelated to the development of juvenile delinquency.

Conclusion: We recommend interventions at the community and family levels. Rehabilitation and academic programmes may help to directly address the issue of juvenile delinquency in Trinidad.
\end{abstract}

Keywords: Juvenile delinquency, risk factors, Trinidad

\section{Factores de Riesgo para la Delincuencia Entre los Jóvenes Adolescentes en Trinidad y Tobago}

A Noel, C Donald, G Hutchinson

\begin{abstract}
RESUMEN
Objetivo: Se han identificado varios factores de riesgo para la delincuencia juvenil, pero no se ha investigado la medida en que son aplicables en Trinidad y Tobago. Llevamos a cabo un estudio de casos y controles, comparando los factores de riesgo en los adolescentes varones delincuentes y no delincuentes.

Métodos: La evaluación del comportamiento delincuente en el transcurso del año anterior se emprendió mediante la escala de delincuencia auto-reportada, mientras que la escala de auto-estima de Rosenberg se utilizó para evaluar la autoestima.

Resultados: Hallamos que el bajo rendimiento académico, las condiciones de vida, y los arrestos de familia, tenían una correlación positiva viviendo medio ambiente y familia detenciones correlacionadas positivamente con la delincuencia en los adolescentes en Trinidad y Tobago. Sin embargo, contrario a nuestras hipótesis, hallamos que la autoestima, el castigo y la estructura familiar (familias mono-parentales) no estaban relacionados con el desarrollo de la delincuencia juvenil.

Conclusión: Recomendamos intervenciones a nivel comunitario y familiar. Los programas de reha-bilitación y los programas académicos pueden ayudar a abordar directamente el tema de la delincuencia juvenil en Trinidad.
\end{abstract}

Palabras claves: Delincuencia juvenil, factores de riesgo, Trinidad

West Indian Med J 2016; 65 (3): 455

From: Psychiatry Unit, The University of the West Indies.

Correspondence: C Donald, Psychiatry Unit, Faculty of Medical Sciences, The University of the West Indies, Mount Hope, Trinidad, West Indies. Fax:

1-868-662-3968, E-mail: casswina@hotmail.com

\section{INTRODUCTION}

The term juvenile delinquency refers to the commission of criminal acts and status offenses by minors (1). A juvenile delinquent is legally defined as someone under the age of 18 years or someone who has not reached the age of maturity who 
commits an act that is punishable by law. Delinquency in general is characterized by deviant behaviour that lies outside of accepted societal norms and includes, theft, substance abuse, larceny, sexual offences and homicide (2). Adolescents exhibiting delinquent behaviour experience significantly adverse outcomes including criminality, school failure, unemployment and poor peer relationships. Furthermore, juvenile delinquents are more likely to become teenage parents and this behaviour tends to be reinforced in their children (3) thus, creating a cycle that is difficult to break. Boys are more likely to be delinquent than girls though the causes for this are unclear. More stringent social controls and less exposure to criminogenic peers have all been postulated to explain this observation (4).

Longitudinal and cross-sectional studies in various societies have identified the risk factors for juvenile delinquency to include socio-economic status (5), academic achievement (6-8) family structure, family arrests $(9,10)$, living environment (11), punishment (12) and self-esteem $(13,14)$.

Causal modelling studies in delinquency suggest harsh punishment, low parental supervision and low academic achievement leads to association with delinquent peers and delinquency activies (15). Most adolescents involved in juvenile delinquent behaviour live in backgrounds with minimal resources and economic deprivation (6). Having a convicted family member (12) predicts a boy's likelihood of delinquency independent of other factors $(10,16)$. Many studies have shown that poor attachment to parents (17) and low parental supervision which are associated with single families are also significantly linked to delinquency. Sauvola et al (16), reports that delinquency rates are $10-15 \%$ higher in single parent homes than intact families and this may be due to the fact that low supervision and weak parent-child relationship $(18,19)$ in conjunction with unemployment and financial hardship exert extra stresses on a single parent family thus, making regular child-monitoring difficult. Well-monitored youths tend to be less involved in delinquency and other norm-breaking behaviour $(20,21)$. One study in the Cameroon showed that most parents of surveyed juvenile delinquents in a correctional institute had low paying jobs which kept them for long periods far away from their children (22). That same study also showed that juvenile delinquents came from homes where both parents were married (22). This suggests that there is no consensus on the role of family status in juvenile delinquency (22). Indeed in a setting where there is a supportive network of people such as: aunts, uncles, grandparents and neighbours, single parenting may not be a risk factor for juvenile delinquency.

Self-esteem is also known to be negatively correlated with delinquency $(13,14)$. This is not surprising given the fact that a vulnerable young person growing-up in an unstable and frightening environment would more than likely have a poor sense of self-esteem. Low self-esteem weakens societal ties (14). According to social bonding theory, weakened ties decrease conformity to societal norms thus, increasing delinquency (23). Individuals who feel a sense of inferiority tend to externalize their behaviour which may lead to hostility towards others (14). Juveniles with low self-esteem are also more prone to join gangs (24). Other research however, points to the fact that high self-esteem may be indicative of egocentrism which may manifest as disregard for and devaluation of others (25).

This study focussed on adolescent boys and attempted to identify the risk factors that may be correlated with delinquency in this population.

\section{SUBJECTS AND METHODS Participants}

A case-control study comparing risk factors in delinquent boys and non-delinquent boys was conducted. Boys from the St Michael's School for Boys were recruited $(n=39$, mean age $=$ 14.9 years) as the delinquent sample. Of this group, twenty-six of the boys were committed and thirteen were remanded to this institution by a court of law after being referred for being out of control.

The non-delinquent sample also consisted of 39 boys (mean age $=15.9$ years) who live and/or attend school in South/Central Trinidad and who had no previous history of disciplinary or deviant behaviour.

\section{Materials and measures}

Three questionnaires were used to collect data for this study. A two page demographic questionnaire was used to assess family status and academic achievement. Assessment of delinquent behaviour over the course of the preceding year was undertaken via the self-report delinquency scale which was developed for the National Youth Survey (26). This scale consists of 45 items which describe specific behaviour and asks for an estimate of the number of delinquent acts. Behaviours to be rated ranged from; "having purposely damaged or destroyed property that belonged to a school" to "how many times in the last-year have you used marijuana". However, because the normative sample used in this survey was based on a North American population, a number of items on the scale were omitted (eg items pertaining to the use of illegal drugs). Additionally terms such as "hiking" were explained to participants. For scoring purposes, the delinquency scale was divided into two parts: 1) Delinquent behaviour and 2) Drug-use. Incidences of delinquent acts were indexed against the hypothesised risk factors. Drug use was indexed against academic achievement, living environment and self-esteem.

The Rosenberg self-esteem scale (27) consisting of a 10item questionnaire which rates responses on a Likert scale with responses ranging from "Strongly Agree" to "Strongly Disagree" was used to assess self-esteem.

\section{Procedure}

We interviewed the thirty-nine adolescent boys from the St Michael's School for Boys. These boys made-up the delinquent set. They met the requirements for delinquency as they were there via court placements for committing violations, 
ranging from substance abuse to minor assaults. The boys were separated into two groups (remand and committed) and interviewed at the school on two separate days.

Post briefing, the questionnaires were administered to the boys. However, because many of them were unable to read, the researcher sometimes assisted with reading and clarifying a few terms in the questionnaires. The boys were instructed to omit three questions pertaining to drug use as these were not applicable to Trinidad's society. The boys in the remand group were all cooperative and total administration time took 1.5 hours. The committed group who were interviewed under the supervision of the school's resident security officers were a bit more disorganized and the interviewer repeated the instructions numerous times. Total administration time for the committed group was one hour 55 minutes.

The non-delinquent sample consisted of 17 boys from the Claxton bay neighbourhood and 22 from the SERVOL life Centre at Forrest Park, Claxton Bay. Permission was given by parents who signed consent forms. Verbal consent was given by some parents who personally knew the researcher. The researcher visited the homes of the non-delinquent boys to administer the questionnaires and their parents had the option to overlook the procedure. As the boys were occupied with school work or extra-curricular activities, administration time took approximately one week.

Permission to administer the questionnaires to the students of SERVOL was granted from the South Regional Coordinator. Administration time took one day. The boys came from the Adolescent Development Programme (ADP) class, automotive repairs and welding class. Administration was done during the recess and lunch break. The total time spent on administering the questionnaires was three hours 30 minutes.

\section{Ethical considerations}

Ethical approval was obtained from the Ethics Committee of the Faculty of Medical Sciences, The University of the West Indies. Participant or parental consent was given either verbally or in writing after the procedure was explained. Prior to the first meeting with participants the manager of the St Michael School for boys was furnished with a copy of the questionnaires in order to ensure that appropriateness was realized. Permission to administer the questionnaires to the students of SERVOL was granted from the South Regional Coordinator.

\section{RESULTS}

The mean scores and standard deviations for the total sample, self-report delinquency and self-esteem are located in Tables $2-4$, respectively.

Table 1 presents the means and standard deviations for the total sample for age.

Table 2 provides the mean scores and standard deviations of the two groups based on the responses given to the self-report delinquency questionnaire. These results indicated
Table 1: Mean scores and standard deviations for age

\begin{tabular}{llll}
\hline & n & Mean & SD \\
\hline Delinquent & 39 & 14.9 & 1.34 \\
Non-delinquent & 39 & 15.9 & 1.39 \\
\hline
\end{tabular}

that delinquent boys scored higher on measures of delinquency compared to those in the non-delinquent group, whose scores were also elevated but not on the level of the delinquent group.

Table 2: Delinquency means and standard deviations between delinquent and non-delinquent groups

\begin{tabular}{llrc}
\hline & n & Mean & SD \\
\hline Delinquent & 39 & 129.08 & 94.95 \\
Non-delinquent & 39 & 55.44 & 40.37
\end{tabular}

Table 3 provides the mean scores and standard deviations of the delinquent and non-delinquent groups for self-esteem. The self-esteem scores for both groups showed minimal differences from which it can be inferred that both groups show high-levels of self-esteem.

Table 3: mean scores and standard deviations on self-esteem for delinquent and non-delinquent groups

\begin{tabular}{lccc}
\hline Rosenberg's self-esteem scale & n & Mean & SD \\
\hline Delinquent & 39 & 30 & 4.31 \\
Non-delinquent & 38 & 32.9 & 2.65 \\
\hline
\end{tabular}

The risk factors identified to be linked to delinquency, ie academic achievement, family background, family arrests, living environment and punishment are compared between two groups and explained as follows:

Eighty-five per cent of the delinquent group showed lower academic achievement whereas in the non-delinquent group, this figure was fifty-six per cent. In the non-delinquent group this figure $(56 \%)$ is somewhat elevated; however, it is still much lower when compared to the delinquent group.

Family structure showed that of the delinquent group, $51 \%$ lived in single parent families (extended/other $=31 \%$, nuclear $=17.9 \%$ ), whereas, $41 \%$ of the non-delinquent group lived within a nuclear family structure (single parent $=38 \%$, extended $/$ other $=22 \%$ ).

Table 4: Family structure percentages

\begin{tabular}{lcc}
\hline Family structure & Delinquent group & Non-delinquent group \\
\hline Single parent & $51 \%$ & $38 \%$ \\
Extended/other & $31 \%$ & $22 \%$ \\
Nuclear & $17.9 \%$ & $41 \%$ \\
\hline
\end{tabular}

The rate of family arrests and/or conviction was $62 \%$ in the delinquent group while in the non-delinquent group the rate was, $44 \%$. Both groups were punished to similar extents (delinquent group $=79.5 \%$ and non-delinquent group $=75 \%$ ).

The majority $(69.2 \%)$ of the delinquent group resided along the East-west corridor while, 30.8\% resided in areas 
comprising of South, Central and Tobago. Within the nondelinquent group, $81.3 \%$ resided in areas comprising of South, Central and Tobago while 18.8\% resided along the East-west corridor.

\section{Correlations}

Table 5: Correlation of family arrests and delinquency

\begin{tabular}{lccc}
\hline & n & r & Sig (two-tailed) \\
\hline Family arrests & 71 & 0.261 & 0.028 \\
\hline
\end{tabular}

Results are significant at $p<0.05$

Table 6: Correlation of academic achievement and drug-use

\begin{tabular}{cccc}
\hline & n & r & Sig (two-tailed) \\
\hline Academic achievement and drug-use & 78 & -0.241 & 0.034 \\
\hline
\end{tabular}

Table 7: Correlation of living environment and drug-use

\begin{tabular}{cccc}
\hline & n & r & Sig (two-tailed) \\
\hline Living environment and drug-use & 77 & 0.242 & 0.034 \\
\hline
\end{tabular}

Table 8: Correlation of self-esteem and drug-use

\begin{tabular}{lccc}
\hline & n & r & Sig (two-tailed) \\
\hline Self-esteem and drug-use & 77 & -0.244 & 0.032 \\
\hline
\end{tabular}

\section{Regression}

A single model fit for delinquency did not emerge using the enter method: $\mathrm{F}(7,62)=2.137, p>0.05$. The model accounts for $10.3 \%$ variance (Adjusted $\mathrm{R}^{2}=0.103$ ). Only living environment $(\beta=0.273, p<0.05)$, family arrests $(\beta=0.312, p<$ $0.05)$ and academic achievement $(\beta=-0.237, p<0.05)$ were found to be significant predictors.

\section{DISCUSSION}

Low academic achievement, living environment and family arrests positively correlated with delinquency in adolescent boys in Trinidad and Tobago. However, contrary to our hypotheses self-esteem, punishment and family structure (single parent families) were found to be unrelated to the development of juvenile delinquency. Preventative intervention in this context should thus, focus on bolstering academic achievement, reducing family arrests and enhancing the living environment. Indeed studies indicate that protective factors against delinquency include low emotional distress and high educational aspirations (6).

We found an inverse relationship existed between lack of academic achievement and participation in delinquent behaviours which is in alignment with prior findings (28). Additionally youth with above average academic achievement while incarcerated are more likely to re-enter school upon release and youth with above average school attendance are significantly less likely to be re-arrested one year post release (8). These suggest that academic achievement is a direct buffer against delinquency. Indeed, the act of performing well at school can serve to also increase self-esteem and self-reliance which in prior studies have been found to be associated with delinquency.

As lack of academic achievement was also found to be a risk factor in Trinidad and Tobago, initiatives aimed at increasing commitment to school and academic achievement could act as a protective measure against delinquency. In Trinidad and Tobago, much emphasis is placed on the academic aspect of school although there are alternative available programmes. Encouraging students who are not academically inclined to re-route into vocational programmes may be one way to halt a delinquent trajectory. Additionally, the introduction and reinforcement of extra-extracurricular activities in schools may be another route. Interventions in delinquency are more favourable the younger the person. Thus, early identification and rechanneling is crucial.

The United Nations World Youth Report [2005] (29) states that urbanization and the area of residence is integral in the development of delinquency. Other findings show that crime rates increase as urbanization increases and economic opportunities decrease (30). We also found that living environment to be significantly associated with the development of delinquency. The majority of the boys in the delinquent group resided along the East-west corridor in Trinidad and Tobago and this area is associated with high levels of urbanization, unemployment, congested housing and high crime rates. The pairing of these with adverse living and family environments could propel an adolescent along a delinquent path. Frequently, vulnerable adolescents live in depressed areas that are lacking in social stability.

Efforts to encourage community cohesion in an attempt to prevent boys who are at risk from becoming influenced by the wrong elements are therefore recommended. Communities can promote development through community events, recreational activities and public awareness of community resources.

Delinquency negatively impacts on childhood and adolescent development because of its strong association with adult criminality. Early effective intervention is likely to reduce this progression and be associated with crime prevention (31). In alignment with prior findings which showed that the conviction of a close relative predicted a boy's own convictions (9) we also found a history of family arrests to be a risk factor. Murray et al explained that this might be due to younger male siblings imitating the older siblings' antisocial behaviour (32). In order to address this, supporting criminal parents and siblings and educating and supporting them via programmes in proper parenting may be useful. This can be accomplished through home visits, parent management training and child skills training. Mentoring of at risk youth with 
older boys who are on a non-delinquent trajectory may serve as an alternative example that these boys emulate. We found no associations between juvenile delinquency and family structure, self-esteem, punishment and socio-economic status.

Fifty-one per cent of the delinquent group and 38\% of the non-delinquent group were boys from single family households. Although the majority of the delinquent group lived within a single family structure, the result was not statistically different thus, we cannot conclusively state that family structure in Trinidad and Tobago is associated with delinquency. Usually a single family status implies other factors are at play such as poor parent-child-monitoring and deficient parent-child ties. In situations, however, where an extended family structure is evident and where aunts, uncles and grandparents or neighbours contribute to child rearing, the risk factor associated with single parenting may be attenuated.

We did not find punishment to correlate with delinquency. The instrument used in assessing this risk factor simply consisted of one question which required a "yes" or "no" answer to "are you punished when you did something goes wrong?" A more in depth probe of this question that addresses other dimensions of punishment (emotional, verbal) as well as the severity of physical punishment may yield different findings. Indeed a lack of punishment may also indicate a lack of instilling discipline in a child and this may in turn point to low parent-child bonding or monitoring which is also a predictor of delinquency.

Using long-term longitudinal assessments versus crosssectional or retrospective surveys may be an improved method of determining causal factors of juvenile delinquency in Trinidad and Tobago. Monitoring a large community population of high-risk youth with regular follow-ups from childhood into adulthood may be the best method of establishing causal factors of juvenile delinquency.

We discovered that an inverse relationship exists between self-esteem and drug-use. This suggests that an adolescent with low self-esteem may be more likely to be involved in drug-use. Reasoner (25) also found that juveniles low in selfesteem to be involved in deviant behaviour such as drug-use in order to compensate for feelings of low self-esteem. We also found that drug-use and lack of academic achievement was inversely correlated with each other suggesting that with low academic achievement a boy is more likely to use drugs. Such a finding may also be attributed to association with delinquent peers and environmental factors.

\section{Limitations}

Compared to previous studies investigating juvenile delinquency, the sample size in this study was relatively small. The results obtained should thus be viewed with caution and not generalized to the wider population. For a more rigorous approach, we advise that a larger sample size be utilized. Additionally, most studies on juvenile delinquency utilize a cross-sectional or retrospective analysis of risk factors. Along with this we suggest that a longitudinal study be undertaken with high-risk youth.

Most studies have found low socio-economic status to be a major risk factor for delinquency hence we matched the two groups by controlling for this. Further research should thus, seek to examine whether socio-economic status is a risk factor for juvenile delinquency in Trinidad and Tobago.

\section{CONCLUSION}

We identified the risk factors associated with delinquency in Trinidad and Tobago to be lack of academic achievement, family arrests and living environment. In line with this, we recommend interventions at the community and family level. Expending community and correctional resources on prevention, rehabilitation and academic programmes may help to directly address the issue of juvenile delinquency in Trinidad and Tobago.

\section{REFERENCES}

1. Remschmidt H, Walter R. What becomes of delinquent children?: Results of the Marburg child delinquency study. Dtsch Arztebl Int 2010; 107: 477-83.

2. Siegel LJ, Welsh BC. Juvenile Delinquency: Theory, Practice and Law, $11^{\text {th }}$ Ed.: Theory, Practice, and Law. Cengage Learning; 2011.

3. Lehti V, Sourander A, Sillanmäki L, Helenius H, Tamminen T, Kumpulainen $\mathrm{K}$ et al. Psychosocial factors associated with becoming a young father in Finland: a nationwide longitudinal study. BMC Public Health 2012; 12: 560 .

4. Weerman FM, Hoeve M. Peers and delinquency among girls and boys: Are sex differences in delinquency explained by peer factors? Eur J Criminol 2012; 9: 228-44.

5. Low S, Sinclair R, Shortt JW. The role of economic strain on adolescent delinquency: a microsocial process model. J Fam Psychol 2012; 26: 57684.

6. Bernat DH, Oakes JM, Pettingell SL, Resnick M. Risk and direct protective factors for youth violence: results from the National Longitudinal Study of Adolescent Health. Am J Prev Med 2012; 43: $57-$ 66.

7. Yun I, Cheong J, Walsh A. The relationship between academic achievement and likelihood of police arrest among delinquents. Int J Offender Ther Comp Criminol [Internet]. 2013 Mar 27 [cited 2013 Oct 17]; Available from: http://www.ncbi.nlm.nih.gov/pubmed/23539519

8. Blomberg TG, Bales WD, Piquero AR. Is educational achievement a turning point for incarcerated delinquents across race and sex? J Youth Adolesc 2012; 41: 202-16.

9. Farrington DP, Jolliffe D, Loeber R, Stouthamer-Loeber M, Kalb LM. The concentration of offenders in families, and family criminality in the prediction of boys' delinquency. J Adolesc Elsevier 2001; 24: 579-96.

10. Shlafer RJ, Poehlmann J, Donelan-McCall N. Maternal jail time, conviction, and arrest as predictors of children's 15-year antisocial outcomes in the context of a nurse home visiting program. J Clin Child Adolesc Psychol 2012; 41: 38-52.

11. Shaw CR, McKay HD. Juvenile delinquency and urban areas. Chicago, IL, US: University of Chicago Press; 1942.

12. Lansford JE, Dodge KA, Pettit GS, Bates JE, Crozier J, Kaplow J. A 12year prospective study of the long-term effects of early child physical maltreatment on psychological, behavioral, and academic problems in adolescence. Arch Pediatr Adolesc Med 2002; 156: 824-30.

13. Barry CT, Grafeman SJ, Adler KK, Pickard JD. The relations among narcissism, self-esteem, and delinquency in a sample of at-risk adolescents. J Adolesc 2007; 30: 933-42.

14. Donnellan MB, Trzesniewski KH, Robins RW, Moffitt TE, Caspi A. Low self-esteem is related to aggression, antisocial behavior, and delinquency. 
Psychol Sci. Sage Publications, Inc. on behalf of the Association for Psychological Science 2005; 16: 328-35.

15. Heilbrun K, Goldestein NES, Redding RE. Juvenile Delinquency: Prevention, Assessment, and Intervention: Prevention, Assessment, and Intervention (Google eBook): Oxford University Press; 2005.

16. Sauvola A, Koskinen O, Jokelainen J, Hakko H, Järvelin M-R, Räsänen P. Family type and criminal behaviour of male offspring: the Northern Finland 1966 Birth Cohort Study. Int J Soc Psychiatry 2002; 48: 115-21.

17. Hoeve M, Stams GJJM, van der Put CE, Dubas JS, van der Laan PH, Gerris JRM. A meta-analysis of attachment to parents and delinquency. J Abnorm Child Psychol 2012; 40: 771-85.

18. Jang SJ, Smith CA. A Test of Reciprocal Causal Relationships among Parental Supervision, Affective Ties, and Delinquency. J Res Crime Delinq 1997; 34: 307-36.

19. Sampson RJ, Laub JH. Urban Poverty and the Family Context of Delinquency: A New Look at Structure and Process in a Classic Study. Child Dev 1994; 65: 523-40.

20. Pathak S. Parental monitoring and Self-disclosure of Adolescents. J Humanit Soc Sci 2012; 5: 01-5.

21. Stattin H. Candid, not monitored children run less risk of becoming delinquent. Lakartidningen 2001; 98: 3009-13.

22. Ngale IF. Family Structure and Juvenile Delinquency: Correctional Centre Betamba, Centre Province of Cameroon. Internet J Criminol [Internet]. 2009; Available from: http://www.internetjournalof criminology.com/Ngale_Family_Structure_and_Juvenile_Delinquency.p dfNgale, I.F. (2009): Family Structure and Juvenile Delinquency: Correctional

23. Hirschi T. Causes of delinquency. Berkeley: University of California Press; 1969.
24. Leary MR, Schreindorfer LS, Haupt AL. The role of low self-esteem in emotional and behavioral problems: Why is low self-esteem dysfunctional? J Soc Clin Psychol. Guilford Publications Inc. 1995; 14: 297-314.

25. Reasoner RW. Review of Self-Esteem Research [Internet]. 2008. Available from: http://www.self-esteem-international.org/content/5research.htm

26. Elliott DS, Huizinga D, Ageton SS. Explaining Delinquency and Drug Use. Beverly Hills, CA: Sage Publications; 1985.

27. Rosenberg M. Society and the adolescent self-image. Princeton, NJ: Princeton University Press; 1965.

28. Jaffe PG, Baker LL. Why Changing the YOA Does Not Impact Youth Crime: Developing Effective Prevention Programs for Children and Adolescents. Can Psychol. Canadian Psychological Association 1999; 40: 22.

29. United Nations World Youth Report. Youth at the United Nations. World Youth Report: Juvenile Delinquency 2005.

30. Black MM, Krishnakumar A. Children in low-income, urban settings: Interventions to promote mental health and well-being. Am Psychol 1998; 53: $635-46$

31. White BAB, Temple JA, Reynolds AJ. Predicting adult criminal behavior from juvenile delinquency: Ex-ante vs. ex-post benefits of early intervention. Adv Life Course Res 2010; 15: 161-70.

32. Murray J, Farrington DP, Olsen RF. Effects of parental imprisonment on child antisocial behaviour and mental health: a systematic review. Campbell systematic reviews 2010; 2009:4. Available from: https:// www.ncjrs.gov/pdffiles1/nij/grants/229378.pdf 